\title{
РЕШЕНИЕ VII ВСЕРОССИЙСКОЙ КОНФЕРЕНЦИИ «НОВЫЕ ДОСТИЖЕНИЯ В ХИМИИ И ХИМИЧЕСКОЙ ТЕХНОЛОГИИ РАСТИТЕЛЬНОГО СЫРЬЯ»
}

VII Всероссийская конференция с международным участием «Новые достижения в химии и химической технологии растительного сырья» состоялась 24-27 апреля 2017 г. в Алтайском государственном университете (Барнаул). Проведение конференции поддержано индустриальными партнерами: ЗАО «Алтайвитамины» (г. Бийск), Биохимический холдинг «Оргхим» (г. Нижний Новгород), ООО «Лаборатория GreenUp» (г. Барнаул).

В работе конференции приняли участие более 200 человек, из них около 100 ученых из 14 городов России и ближнего зарубежья (Архангельск, Минск, Москва, Иваново, Бийск, Барнаул, Новосибирск, Красноярск, Томск, Сургут, Караганда, Иркутск, Ханты-Мансийск, Благовещенск), представители более 40 научных и научно-производственных организаций. Авторами 217 материалов, опубликованных в сборнике, являются 418 ученых, работающих в 120 организациях из семи стран (Армения, Беларусь, Грузия, Казахстан, Россия, Узбекистан, Украина). Материалы, опубликованные в сборнике, распределены между направлениями работы конференции следующим образом: 52 - посвящены строению и свойствам основных компонентов и тканей в процессах химической переработки растительного сырья; 100 - в разделе «Состав, строение, физико-химические и медико-биологические свойства экстрактивных веществ, выделенных из растительного сырья»; 41 - «Усовершенствование действующих и создание новых технологий химической переработки растительных материалов. Химия и технология целлюлозы и бумаги»; 24 - «Биотехнологические методы при переработке растительного сырья».

На конференции прочитано и обсуждено 14 пленарных докладов. Работало три секции. На секции «Строение и свойства основных компонентов и тканей в процессах химической переработки растительного сырья» заслушано 23 доклада, на секции «Низкомолекулярные компоненты растительного сырья: строение, свойства, химическое модифицирование, технологии получения, БАВ» - 25 докладов; на секции «Усовершенствование действующих и создание новых технологий химической переработки растительных материалов. Химия и технология целлюлозы и бумаги. Высокоэффективная переработка древесного и другого целлюлозосодержащего сырья методами биотехнологии» - восемь. Проведена стендовая сессия.

\section{Результаты конференции}

Участники конференции обсудили актуальные проблемы, дали оценку текущему состоянию и предложили некоторые пути решения проблем, поставленных в государственной программе Российской Федерации «Развитие промышленности и повышение ее конкурентоспособности» в части, касающейся научных исследований в области химической, биотехнологической, биофармацевтической переработки растительного сырья.

Учеными научно-исследовательских, научно-производственных, производственных и образовательных учреждений и организаций России и других государств за прошедшие три года внесен значительный научный и практический вклад в развитие технологий переработки разнообразного растительного сырья.

Это результаты фундаментальных и прикладных исследований в следующих областях:

- состав, строение, физико-химические и медико-биологические свойства экстрактивных веществ, выделенных из растительного сырья, трансформация природных веществ в лекарственные средства; 
- строение и свойства основных компонентов и тканей в процессах химической переработки растительного сырья, усовершенствование действующих и создание новых технологий химической переработки растительных материалов;

- химия и технология целлюлозы и бумаги;

- высокоэффективная переработка древесного и другого целлюлозосодержащего сырья методами биотехнологии.

Результаты исследований, представленные в материалах конференции, направлены на реализацию стратегий развития, обозначенных в Комплексной программе развития биотехнологий (24 апреля 2012 г. № 1853п-П8) и программы «Развитие фармацевтической и медицинской промышленности» (от 15 апреля 2014 г. № 305.) Российской Федерации на период до 2020 года и дальнейшую перспективу.

Более 10\% работ, материалы которых опубликованы в сборнике материалов конференции, поддержаны российскими и международными научными фондами, федеральными целевыми программами и региональными грантами.

\section{Решения конференции}

1. Считать Всероссийскую научную конференцию с международным участием «Новые достижения в химии и химической технологии растительного сырья» научно-практической информационной платформой, являющейся существенной частью для развития технологического рынка в области переработки растительного сырья.

2. Отметить системообразующую роль журнала «Химия растительного сырья» в информационной и методической поддержке научного сообщества в области переработки растительного сырья и программной подготовке конференции.

3. Акцентировать внимание ученых на исследовании биотехнологических способов переработки растительного сырья.

4. Направить информацию о результатах VII Всероссийской научной конференции с международным участием «Новые достижения в химии и химической технологии растительного сырья» в Департамент химико-технологической и лесоперерабатывающей промышленности, Департамент фармацевтической и медицинской промышленности Министерства промышленности и торговли РФ, технологическую платформу «Биоиндустрия и биоресурсы БиоТех 2030».

5. Информацию об итогах конференции разместить в журнале «Химия растительного сырья».

6. Организовать в 2020 г. проведение VII1 Всероссийской научной конференции с международным участием «Новые достижения в химии и химической технологии растительного сырья» в г. Барнауле на базе ФГБОУ ВО «Алтайский государственный университет».

Оргкомитет выражает благодарность фармацевтической компании ЗАО «Алтайвитамины», биохимическому холдингу «Оргхим», ООО «Лаборатория GreenUp» за финансовую и материально-техническую поддержку при проведении конференции.

Программный комитет конференщии 